\title{
Organizational Commitment-Rewards Relationship and Its Change in Japanese Companies in China
}

\author{
Keisuke Kokubun ${ }^{1}$ \\ ${ }^{1}$ International Economy and Work Research Institute, Osaka, Japan \\ Correspondence: Keisuke Kokubun, International Economy and Work Research Institute, 3-14 \\ Kitahama-Higashi, Chuo-ku, Osaka, 540-0031, Japan.
}

Received: May 25, 2017

doi:10.5539/ibr.v10n7p155

\author{
Accepted: June 19,2017 Online Published: June 26, 2017 \\ URL: https://doi.org/10.5539/ibr.v10n7p155
}

\begin{abstract}
This study investigates a transition of the relationship between rewards and the organizational commitment of total 1,005 uni versity graduates who work for 4 Japanese companies in China. Hierarchical regression analysis revealed that supervisor support had stronger influence on organizational commitment in 2013 than it did in 2007, showing that the employees became to require more support from supervisors than before due to a growing anxiety under economic slowdown since the global financial crises of 2008. This result indicates that employees may become more collectivistic during a period of economic growth stagnation. Discussions and implications concerning human resource management of Japanese companies in China are offered.
\end{abstract}

Keywords: change, China, exploratory factor analysis, Japanese companies, organizational commitment, rewards, university graduates

\section{Introduction}

Among developing countries, China is the largest recipient of foreign direct investment (FDI) and has the largest number of employees who work for foreign companies (United Nations Conference on Trade and Development, 2010). Indeed, approximately 24 million employees (3\% of China's total employment) were employed by foreign companies in China (United Nations Conference on Trade and Development, 2004). Among them, Japanese companies continue to benefit from China's growth and remain one of the leading investors in China, which accounted for $6.0 \%$ of the total effective FDI in 2013 and became China's third largest source of foreign capital, following Hong Kong and Singapore (Japan External Trade Organization, 2016). The number of Japanese companies located in China in the end of 2012 was 23,094, which accounted for the highest share 7.9\% of total foreign companies in China (The Japanese Chamber of Commerce and Industry in China, 2016). The number of employees who work for Japanese companies in China in 2015 was 1.62 million, which accounted for 40.5 percent of total employees of Japanese companies in Asia (Ministry of Economy, Trade and Industry of Japan, 2016).

However, the major economic crisis that originated in the United States in 2008 also affected China and it is said that tens of thousands of foreign-invested companies in the eastern provinces collapsed with millions of people losing their jobs (Zhou \& Lin, 2009). The number of Japanese companies also decreased by more than 2,500 in 2009 after increase by more than 11,000 between 2000 and 2008. Although the number started to increase again in 2010, the growth rate has been lower than before (Shibata, 2015). Meanwhile, real GDP growth rate has decreased remarkably: Before the crises, it was 10.0 (2003), 10.1 (2004), 11.3 (2005), 12,7 (2006) and 14.2 (2007) percent; After the crises, it changed to 9.6 (2008), 9.2 (2009), 10.6 (2010), 9.5 (2011), 7.9 (2012), 7.8 (2013), 7.3 (2014), 6.9 (2015) and 6.7 (2016) percent annually (International Monetary Fund, 2017). Besides, with an alarming rise in the number of unemployed and under-employed graduates, a large group of educated young people are becoming alienated and unable to become part of the growing middle class (Sharma, 2014). The unemployment rate of graduates was higher than 30 percent in 2008 and still around 30 percent in 2014 (Sharma, 2014; Zhou \& Lin, 2009).

In this long-standing social unrest, it is necessary to determine how the nature of university graduates has been changed over time for the management of Japanese companies to obtain useful hints to utilize their abilities or to retain them in the present company for the maintenance or further improvement of their competitiveness in China and the world. So, this study analyzes the transition of relationship between organizational commitment 
(OC) and its antecedents of university graduates who are employed by Japanese firms between 2007 and 2013. OC is defined as the employees' state of being committed to assist in the achievement of the organization's goals, and involves the employees' levels of identification, involvement, and loyalty (Caught \& Shadur, 2000). The reason why the researcher focuses on the antecedents of OC is because OC is seen as a prime explanation for why some desire to remain employed while others do not (Allen \& Meyer, 1990; Mowday, Porter, \& Steers, 1982; Peyyer, Jordan, Firms, \& Travaglione, 2010; Steers, 1977) or why some have a high work performance while others do not (Meyer, Stanley, Herscovitch, \& Topolnytsky, 2002; Phipps, Prieto, \& Ndinguri, 2013). OC is also known to be related with the corporate innovation and creativity (Hou, Gao, Wang, \& Yu, 2011; Jafri, 2010).

\section{Literature Review}

\subsection{Organizational Rewards in China}

The achievement of an organization does not only rely on how the organization utilizes its human capitals and competencies but also on how it incites commitment to the organization (Beukhof, De Jong, \& Nijhof, 1998). Barrett and O'Connell (2001) argue that employees may view some human resource practices as a reward. The result of this reward is that employees have a greater sense of debt, feel like insiders and are more committed to the organization.

Several studies conducted in China also show that $\mathrm{OC}$ is strongly related to the employee's intention to leave or stay with the organization and it plays a vital role to strengthen the organization growth (Nazir, Shafi, Qun, Nazir, $\&$ Tran, 2016). In addition, another study has indicated a strong link between OC and organizational innovation (Ming \& Zhao ying, 2010). The antecedents significantly correlated with OC in previous study in Chinese setting were: support from supervisors/colleagues (He, Lai, \& Lu, 2011; Lam \& O'Higgins, 2011; Miao, Newman, Sun, \& Xu, 2013; Nazir, et al., 2016; Newman \& Sheikh, 2012; Wang, 2008); financial compensation (Chiu, Luk \& Tang, 2002; Nazir, et al., 2016; Newman \& Sheikh, 2012); stress (Jamal, 2005); autonomy or discretional power (Chen \& Aryee, 2007; Froese \& Xiao, 2012; Miao et al., 2013; Nazir, et al., 2016; Newman \& Sheikh, 2012); training or skill/ ability provision (Nazir, et al., 2016; Newman, Thanacoody, \& Hui, 2011); role clarity (Newman \& Sheikh, 2012), etc. Following these pieces of research, this paper supposes seven rewards as the antecedents of OC. They are: supervisor support; co-worker support; benefit satisfaction; fatigue; autonomy; training provision; and role clarity.

These rewards are sometimes classified into three groups: i.e. intrinsic rewards, extrinsic rewards and social rewards. In previous research, intrinsic rewards comprised autonomy, training provision and role clarity; extrinsic rewards included benefit satisfaction and fatigue; social rewards contained supervisor support and co-worker support (e.g., Kokubun, 2017a). Porter and Lawler (1968) defined intrinsic rewards as the satisfaction that a person derives from doing the job and extrinsic rewards as tangible benefits obtained as a result of doing the job, such as pay and promotions. On the other hand, according to Mottaz (1985), social rewards refer to those that are derived from interpersonal relationships with colleagues and supervisors. Previous works suggest that: (i) intrinsic rewards have a greater impact on OC of employees in the West than extrinsic or social rewards (Eby, Freeman, Rush, \& Lance, 1999; Malhotra, Budhwar, \& Prowse, 2007; O'Reilly \& Caldwell, 1980); and (ii) extrinsic and social rewards have a greater impact on OC of Chinese employees than intrinsic rewards (Miao, et al., 2013; Newman \& Sheikh, 2012).

As it was found by Hofstede (1980) that culture of a country changes as its economy develops, difference between '(i)' and '(ii)' might be attributed not only to geographical features such as the West and the East but also to economic stages on which each country is placed. Furthermore, Boyacigiller and Adler (1991) argue that the commitment of employees with collectivist values may arise from ties with managers, owners, and co-workers, whereas the commitment of employees with an individualist orientation may be due to the job itself or the compensation system. If these assertions are true, the reason of '(i)' might be attributed as follows: as Western countries are overall more developed than others, employees are more individualistic and intrinsic rewards are accordingly more important for OC. On the other hand, for '(ii)', it may be assumed that: as China is less developed than Western countries, employees are less individualistic and social rewards are accordingly more important for OC. The reason why extrinsic rewards are important for OC of employees in China in spite of its collectivistic culture will be that economy of China is still in transition and most employees have to work for resources for subsisting.

Although these studies much contributed to understanding of OC in China, it is unclear how the association between these rewards and OC change over time, especially in economically good times or bad times. The present study is the first to research changes in the relationship between OC and rewards in China using the 
sample of employees who work for four Japanese affiliates. The survey was conducted in 2007 and 2013, which permits us to see the changes before and after the financial crisis in 2008. The author expects that this study enable us to advise corporate managers in China as to what strategies may be effective to foster high levels of OC amongst university graduates when it is under a circumstance of economic slowdown.

\subsection{Moderating Role of Year}

Previous research suggests that individualism could be increasing in China (Yan, 2009), and that such a trend is likely to be most evident in more economically developed parts of the country (Gamble \& Tian, 2015; Ralston, Holt, Terpstra, \& Kai-Cheng, 2008). If we could apply these findings to this research, we might be able to expect that individualism is strengthened during the boom while collectivism is strengthened during the bust. As the survey period in this paper corresponds to the latter, it is considerable that Chinese employees may have become more collectivistic reflecting the long lasting economic slowdown. This leads us to the following hypotheses:

Hypothesis 1: Relationship between supervisor support and OC is positively stronger in 2013 than in 2007.

Hypothesis 2: Relationship between co-worker support and OC is positively stronger in 2013 than in 2007.

Both supervisor support and co-worker support are classified as 'social rewards' in the previous research and are said to be stronger in relation with OC in collectivistic society (Boyacigiller \& Adler, 1991). Especially, supervisors are said to have a greater influence on the work activities of their subordinates in Chinese organizations than is the case in the West due to a cultural context in which there is respect for seniority, strict hierarchies in the workplace and limited subordinate participation in decision-making (Chan, Feng, Redman, \& Snape, 2006; Cheng, Jiang \& Riley, 2003; Chen, Tsui \& Farth, 2002). If it is true that such collectivistic culture was more typical in the past and has become weaker as the society has developed economically, it may not be unreasonable to consider that people become more collectivistic and require more support from peers in a period of economic stagnation. Then, what about other rewards? If we expect that individualism is weakened during the economic slowdown, the relations of extrinsic and intrinsic rewards with OC may also become weaker as they are known to be stronger in individualistic societies (Boyacigiller \& Adler, 1991). However, the researcher is reluctant to accept such assertion because individualism is not the antonym of collectivism (Triandis, Bontempo, Villareal, Asai, \& Lucca, 1988). Indeed, Asian countries have adopted market economic perspectives and become more individualistic without substantially forsaking their collectivistic Confucian roots. Accordingly, developing economies have created their own unique hybrid version of a market economy, integrating traditional cultures with new economic ideology (Ralston, Nguyen, \& Napier, 1999). Furthermore, it may also be possible to consider that the relations of these rewards with $\mathrm{OC}$ become stronger as laborers face more difficulties to find a workplace of reasonable treatments and work fulfillments during hard times. Anyway, the fact that the study regarding the change of $\mathrm{OC}$ and its rewards is quite limited tentatively leads us to the following hypotheses:

Hypothesis 3: Relationship between benefit satisfaction and OC is equally strong (weak) in 2007 and in 2013.

Hypothesis 4: Relationship between fatigue and OC is equally strong (weak) in 2007 and in 2013.

Hypothesis 5: Relationship between autonomy and OC is equally strong (weak) in 2007 and in 2013.

Hypothesis 6: Relationship between training provision and OC is equally strong (weak) in 2007 and in 2013.

Hypothesis 7: Relationship between role clarity and OC is equally strong (weak) in 2007 and in 2013.

Totally, we suppose the support from supervisors and co-workers became more correlated with OC during the period of stagnation between 2007 and 2013 leaving the relations of other rewards and OC unchanged based on an understanding that collectivism became stronger leaving individualism unchanged.

\subsection{Japanese Companies' HRM Performance in China}

As we suppose that the supervisor support becomes more related with OC during hard times, let us review what local employees think about Japanese companies before proceeding analyses. The Japanese manufacturing workplace has been characterized by commitment, loyalty and lower rates of turnover, absenteeism and industrial conflict along with high levels of productivity and product quality (Colignon, Usui, \& Kerbo, 2007). Besides, it has been argued that elements of Japanese management, such as secure employment or an emphasis on seniority, are still strongly present in Japanese overseas subsidiaries, and that such practices may even be more appropriate for countries that are developing economically (Wasti, 1998). However, in contrast, previous survey conducted in China has indicated that Japanese companies do not rank among the most popular employers, and are even frequently named as those that people would least want to work for (Zhang, 2003). Likewise, Yu and Meyer-Ohle (2008) revealed that employees who worked for Japanese companies had more complaints than those who worked for Western companies by interview surveys to employees who worked for 
Japanese and Western companies in China.

Actually, Japanese companies face great numbers of employees resigning from their positions: i.e., the separation rate for regular workers and university graduates were 11.5 and 12.4 percent respectively (Japan-China Investment Promotion Organization, 2005). Another study reveals that separation rates in Japanese companies and the Western companies in Shang Hai were 15.2 and 6.3 percent respectively, where the former is more than the double of the latter. Especially, the score is high, around 30 percent, for special and technical staffs (Recruit Management Solutions, 2012). Such a high separation rate in Japanese affiliates is sometimes attributed to its inadequate localization and insufficient communication between Chinese staffs and Japanese expatriates who are replaced in 3 to 4 years (Wan, 2009). Actually, previous survey revealed that Japanese managers in China received poorer evaluations from their subordinates than local managers do especially for job performing ability, leadership and capability for managing subordinates (Shiraki, 2012). From these findings, HRM of Japanese companies may not be fully effective for enhancing OC of employees at least in particular groups who have confidence on their skills and have more opportunities to work directly with Japanese expatriates such as university graduates, although might be effective to some extent for general employees in China. If these assertions are true, supervisors in Japanese companies in China may face some barriers to provide uni versity-graduate employees appropriate support which could be perceived as the rewards worth reciprocating. Off course, supervisors are not only Japanese expatriates but in most cases Chinese managers, but even the latter may be influenced by the former and vary in its quality if a company couldn't educate the latter appropriately or couldn't hire the latter with high management skills.

\section{Methods}

\subsection{Participants}

We sent questionnaires to employees in 4 Japanese manufacturing companies in China from April to November 2007. We purposely selected Japanese companies in China instead of other kinds, such as state-owned or other private companies as the latter has a different set of HRM practices and many organizational variables would not be eligible for legitimate comparison with Japanese counterparts (Warner, 2004). 700 questionnaires were distributed via the HR department of participant companies. The participation was basically compulsory. With a promise to present the summary results, the HR department of each firm administered the questionnaires by distributing and collecting completed questionnaires. Each respondent was requested to put the completed questionnaire into an envelope that the researcher provided along with the questionnaire and seal it for him/her self to guarantee complete anonymity. Overall, 613 surveys were collected, reflecting a response rate of $87.6 \%$. We eliminated 184 surveys due to missing values or inappropriate participants for this research (e.g. contract employees, foreign workers, Japanese expatriates, etc.). Consequently, the final samples comprised 429 Chinese participants.

Again, we sent the same questionnaires to employees in the same 4 Japanese companies between May 2013 and February 2014. 800 questionnaires were distributed and 698 surveys were collected, reflecting a response rate of $87.3 \%$. We eliminated 122 surveys due to the same reason above and consequently the final samples comprised 576 Chinese participants. In this research, we use these data sets to calculate how the nature of employees has changed in terms of the rewards-organizational commitment between 2007 and 2013. Among 4 companies, three were electrical and another was automobile makers. Geographically, two were in Dalian city (Liaoning province), one was in Wuxi city (Jiangsu province) and another was in Dongguan city (Guangdong province). For reference, the numbers of major Japanese companies located in these provinces were 288, 629 and 614, which accounted for 7.0, 15.3 and 14.9 percent of the total in China, respectively (Yan, 2010). The sample four companies are all subsidiaries of well known big Japanese companies listed on the first section of the Tokyo Stock Exchange. The total number of employees who work for these four companies was more than 6,000 in 2013. So, the researcher considers that the sample appropriately reflects the entire tendencies of university graduates in Japanese companies in China. Other demographic information of the participants is shown in tables of appendix. We controlled for all the demographic variables in order to attenuate any concern about sample compatibility.

\subsection{Measures}

The questions are obtained from Kokubun (2006), in which OC was correlated with various rewards in Malaysian setting. Recent research by Kokubun (2017a; 2017b) confirmed such correlations in setting of Thailand and Malaysia using the same questions, too. Accordingly, the researcher expects the similar association between the variables of reward and OC described below because these countries and China share similarities in geographical and cultural spheres (e.g., collectivism, high-power distance, etc. Cf. Hofstede, 1980). They are measured on a five-point scale. The original questionnaire was developed in English and then translated into 
Chinese. To ensure the accuracy of the translation, the questionnaire was then translated back.

\subsubsection{Supervisor Support}

Supervisor support was measured on a five-item scale. The alpha reliability was 0.863 for the 2007 and 0.898 for the 2013.

\subsubsection{Co-worker Support}

Co-worker support was measured on a four-item scale. The alpha reliability was 0.804 for the 2007 and 0.859 for the 2013.

\subsubsection{Benefit Satisfaction}

Benefit satisfaction was measured on a three-item scale. The alpha reliability was 0.759 for the 2007 and 0.826 for the 2013.

\subsubsection{Fatigue}

Fatigue was measured on a three-item scale. The alpha reliability was 0.777 for the 2007 and 0.854 for the 2013 .

\subsubsection{Autonomy}

Autonomy was measured on a three-item scale. The alpha reliability was 0.548 for the 2007 and 0.625 for the 2013.

\subsubsection{Training Provision}

Training provision was measured on a three-item scale. The alpha reliability was 0.632 for the 2007 and 0.792 for the 2013.

\subsubsection{Role Clarity}

Role clarity was measured on a two-item scale. The alpha reliability was 0.674 for the 2007 and 0.772 for the 2013.

\subsubsection{Organizational Commitment}

Six items were used to measure OC. The alpha reliability was 0.818 for the 2007 and 0.881 for the 2013 .

\subsubsection{Control Variables}

Several demographic variables were included to control for individual differences. Answered figures without any conversion were used for age and organizational tenure. Sample dummy shows the survey year whether 2007 or 2013. Gender, turnover experience, marital status, indirect/direct department, managerial/non-managerial position were also measured. Three dummy variables were created to control for the four different companies.

\section{Results}

We conducted an exploratory factor analysis of all items (except control variables) to examine measurement invariance between the samples of 2007 and 2013. The results of the factor analysis with varimax rotation are presented in Table 1, confirming a eight-factor solution for all the items of supervisor support, co-worker support, benefit satisfaction, fatigue, autonomy, training provision, role clarity and OC. The factor structure was the same for the 2007 and the 2013; therefore, we are convinced that both employees in 2007 and those in 2013 ascribed the same meanings to the scale items used in the current study (Milfont \& Fischer, 2010).

Descriptive statistics for both the 2007 and the 2013 samples are presented in Table 2. We tested our hypotheses using hierarchical regression analysis. We entered the control variables in Step 1 and main effects of supervisor support, co-workers support, benefit satisfaction, fatigue, autonomy, training provision and role clarity in Step 2. In Step 3, we entered the sample variable ( 1 for the 2013 and 0 for the 2007) and its interaction terms with main effects for the entire sample to test the moderation. Variables forming the interaction term were entered to minimize multicollinearity among the interaction terms and their components (Akien \& West, 1991). In addition, we conducted separate regression analysis using the 2007 and the 2013 data. All regression results are presented in Table 3.

Step 1 presents the results when only the control variables are included in the regression to predict OC. Out of seven demographic variables, only one variable, gender, was found to influence OC negatively $(\beta=-0.11, p<$ 0.01 ). That means that female employees tend to have higher OC than male ones.

Step 2 presents the results when all the seven reward variables are added to the regression. Fatigue is negatively and the other six reward variables are positively associated to the regression significantly $(\mathrm{p}<0.01)$. Observing adjusted R2, these rewards explained $41 \%$ of additional variance in OC. This implies that all of rewards are 
important for OC.

At step 3, the relationship between supervisor support and OC was moderated by the sample, showing that their relationship was stronger in 2013 than in $2007(\beta=0.30, p<0.05)$. In other words, university graduates' OC in 2013 was more affected by supervisor support than it was in 2007. On the other hand, the relationships of other variables with OC showed no significant difference between 2007 and 2013. The significant results of these moderation tests are consistent with the Hypotheses 1 and 3 to 7 but inconsistent with the Hypothesis 2 .

Items

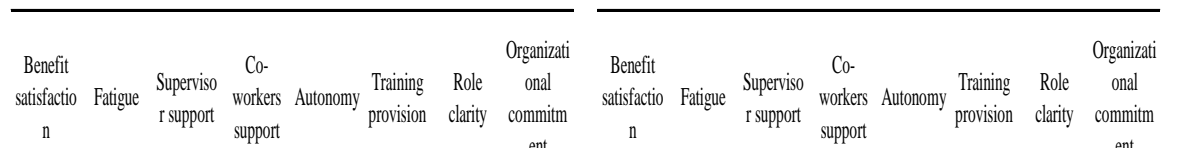

\section{Possibility of my promotion.}

Amount of my salary or wage.

My position or rank at the working place.

I often feel exhausted.

After finishing my work, I feel exhausted.

Ifeel exhausted when I wake up in the morning.

My boss/supervisor is trustful.

My boss/supervisor treats employees fairly.

My boss/supervisor deals with employees' complaints effectively.

My boss/supervisor trusts workers.

My bossssupervisor is willing to instruct the employees what they do not know about their work.

Relationship with my co-workers and subordinates.

Evaluation by my $\mathrm{co}$-workers and subordinates.

Ability of my co-workers and subordinates.

Human relationship at my working place.

I can mostly solve the problems that arise in my work.

The level of my skill in the company is higher than the average.

I carry out my work by observing and planning it by myself.

For the past one year, I was given useful training to develop ability and achieve my target.

In my work, I can master new skills and develop my ability

At work, the bosses/supervisors and the seniors are training their subordinates.

The work division that I have to do is clearly identified.

The division of labor between my co-workers and I is clear.

I am willing to contribute to development of this company.

I have dreams about the future of my company and its work.

I have strong will to work hard in this company.

I want to be employed by this company as long as possible.

My company makes very meaningful contributions to this society.

I am attracted to the slogan of the company and the strategies to achieve it.

$\begin{array}{llllllll}0.60 & -0.07 & 0.25 & 0.10 & 0.13 & 0.25 & 0.04 & 0.17 \\ 0.60 & -0.08 & 0.15 & 0.09 & -0.14 & 0.07 & 0.04 & 0.22 \\ 0.69 & -0.11 & 0.18 & 0.22 & -0.03 & 0.14 & 0.12 & 0.19\end{array}$

$\begin{array}{llllllll}-0.05 & 0.88 & -0.03 & -0.15 & 0.01 & -0.04 & -0.03 & -0.13\end{array}$

$\begin{array}{llllllll}-0.07 & 0.71 & 0.02 & 0.05 & 0.02 & -0.03 & -0.07 & -0.09\end{array}$

$\begin{array}{llllllll}-0.07 & 0.60 & -0.10 & -0.14 & -0.04 & -0.11 & -0.01 & -0.09\end{array}$

$\begin{array}{llllllll}0.07 & -0.02 & 0.84 & 0.09 & 0.01 & 0.06 & 0.11 & 0.21\end{array}$

$\begin{array}{llllllll}0.21 & -0.05 & \mathbf{0 . 7 0} & 0.10 & 0.09 & 0.09 & 0.09 & 0.24\end{array}$

$\begin{array}{llllllll}0.26 & -0.05 & 0.65 & 0.16 & 0.05 & 0.13 & 0.08 & 0.13\end{array}$

$\begin{array}{llllllll}0.08 & -0.03 & 0.76 & 0.10 & 0.14 & 0.05 & 0.10 & 0.08\end{array}$

$\begin{array}{llllllll}0.06 & -0.01 & \mathbf{0 . 5 4} & 0.15 & -0.02 & 0.17 & 0.11 & 0.03\end{array}$

$\begin{array}{llllllll}0.02 & -0.07 & 0.14 & 0.71 & 0.13 & 0.09 & 0.02 & 0.13\end{array}$

$\begin{array}{llllllll}0.03 & -0.09 & 0.11 & 0.71 & 0.16 & 0.17 & 0.02 & 0.12\end{array}$

$\begin{array}{llllllll}0.19 & -0.04 & 0.16 & 0.63 & -0.03 & 0.08 & 0.07 & 0.11\end{array}$

$\begin{array}{llllllll}0.16 & -0.07 & 0.11 & 0.66 & 0.15 & -0.03 & -0.02 & 0.16\end{array}$

$\begin{array}{llllllll}-0.01 & -0.04 & 0.08 & 0.16 & 0.61 & 0.03 & 0.09 & 0.11\end{array}$

$\begin{array}{llllllll}-0.07 & 0.09 & 0.01 & 0.08 & 0.54 & 0.01 & -0.06 & 0.05\end{array}$

$\begin{array}{llllllll}0.08 & -0.11 & 0.08 & 0.06 & 0.42 & 0.00 & 0.22 & 0.24\end{array}$

$\begin{array}{llllllll}0.29 & -0.07 & 0.13 & 0.05 & -0.07 & \mathbf{0 . 5 3} & 0.05 & 0.15\end{array}$

$\begin{array}{llllllll}0.14 & -0.17 & 0.18 & 0.14 & 0.06 & \mathbf{0 . 5 0} & 0.08 & 0.25\end{array}$

$\begin{array}{llllllll}0.08 & -0.05 & 0.28 & 0.20 & 0.11 & \mathbf{0 . 4 3} & 0.00 & 0.21\end{array}$

$\begin{array}{llllllll}0.07 & -0.02 & 0.17 & 0.04 & -0.03 & -0.01 & 0.68 & 0.14\end{array}$

$\begin{array}{llllllll}0.07 & -0.09 & 0.17 & 0.00 & 0.16 & 0.11 & 0.69 & 0.10\end{array}$

$\begin{array}{llllllll}0.08 & -0.12 & 0.04 & 0.14 & 0.11 & 0.09 & 0.08 & 0.65\end{array}$

$\begin{array}{llllllll}0.15 & -0.06 & 0.18 & 0.06 & 0.10 & 0.09 & 0.07 & \mathbf{0 . 7 0}\end{array}$

$\begin{array}{llllllll}0.05 & -0.05 & 0.14 & 0.07 & 0.06 & 0.10 & 0.06 & 0.67\end{array}$

$\begin{array}{llllllll}0.31 & -0.04 & 0.16 & 0.11 & 0.12 & 0.14 & 0.14 & 0.51\end{array}$

$\begin{array}{llllllll}0.01 & -0.05 & 0.14 & 0.14 & 0.18 & 0.21 & 0.03 & \mathbf{0 . 4 8}\end{array}$

$\begin{array}{llllllll}0.21 & -0.10 & 0.06 & 0.12 & -0.03 & 0.01 & 0.06 & 0.59\end{array}$

\begin{tabular}{llllllll}
\hline $\mathbf{0 . 7 4}$ & 0.10 & 0.23 & 0.21 & 0.05 & 0.16 & 0.05 & 0.24 \\
0.63 & 0.16 & 0.16 & 0.09 & 0.06 & 0.12 & 0.06 & 0.27
\end{tabular}

$\begin{array}{llllllll}0.63 & 0.16 & 0.16 & 0.09 & -0.06 & 0.12 & 0.06 & 0.27\end{array}$

$\begin{array}{llllllll}\mathbf{0 . 5 9} & 0.13 & 0.22 & 0.26 & -0.11 & 0.24 & 0.11 & 0.29\end{array}$

$\begin{array}{llllllll}-0.07 & -0.94 & -0.09 & -0.13 & -0.01 & -0.02 & -0.08 & -0.11\end{array}$

$\begin{array}{llllllll}-0.11 & -0.75 & -0.09 & -0.10 & 0.03 & -0.07 & -0.08 & -0.06\end{array}$

$\begin{array}{llllllll}-0.09 & -0.69 & -0.12 & -0.02 & -0.09 & -0.06 & -0.04 & -0.19\end{array}$

$\begin{array}{llllllll}0.16 & 0.09 & 0.80 & 0.17 & 0.07 & 0.07 & 0.07 & 0.24\end{array}$

$\begin{array}{llllllll}0.25 & 0.08 & 0.77 & 0.19 & 0.07 & 0.15 & 0.16 & 0.21\end{array}$

$\begin{array}{llllllll}0.18 & 0.09 & 0.69 & 0.17 & 0.11 & 0.21 & 0.11 & 0.24\end{array}$

$\begin{array}{llllllll}0.12 & 0.15 & 0.65 & 0.17 & 0.04 & 0.11 & 0.11 & 0.17\end{array}$

$\begin{array}{llllllll}0.01 & 0.06 & 0.63 & 0.22 & 0.03 & 0.17 & 0.09 & 0.20\end{array}$

$\begin{array}{llllllll}0.06 & 0.07 & 0.25 & 0.77 & 0.18 & 0.13 & 0.11 & 0.12\end{array}$

$\begin{array}{llllllll}0.22 & 0.06 & 0.16 & \mathbf{0 . 7 2} & 0.18 & 0.09 & 0.09 & 0.17\end{array}$

$\begin{array}{llllllll}0.15 & 0.10 & 0.18 & 0.64 & -0.03 & 0.19 & 0.11 & 0.19\end{array}$

$\begin{array}{llllllll}0.07 & 0.12 & 0.26 & 0.62 & 0.01 & 0.19 & 0.14 & 0.21\end{array}$

$\begin{array}{llllllll}-0.01 & 0.03 & 0.03 & 0.14 & 0.70 & 0.04 & 0.11 & 0.13\end{array}$

$\begin{array}{llllllll}-0.07 & -0.01 & 0.02 & 0.00 & 0.57 & -0.04 & -0.04 & 0.03\end{array}$

$\begin{array}{llllllll}0.13 & 0.07 & 0.23 & 0.14 & \mathbf{0 . 5 0} & 0.11 & 0.20 & 0.25\end{array}$

$\begin{array}{llllllll}0.23 & 0.06 & 0.17 & 0.18 & -0.01 & \mathbf{0 . 7 2} & 0.11 & 0.21\end{array}$

$\begin{array}{llllllll}0.15 & 0.09 & 0.22 & 0.25 & 0.07 & 0.62 & 0.08 & 0.22\end{array}$

$\begin{array}{llllllll}0.08 & 0.05 & 0.33 & 0.23 & 0.01 & \mathbf{0 . 5 2} & 0.15 & 0.25\end{array}$

$\begin{array}{llllllll}0.06 & 0.07 & 0.18 & 0.15 & 0.15 & 0.11 & 0.84 & 0.09\end{array}$

$\begin{array}{llllllll}0.09 & 0.12 & 0.16 & 0.16 & 0.01 & 0.11 & \mathbf{0 . 6 3} & 0.19\end{array}$

$\begin{array}{llllllll}0.10 & 0.11 & 0.30 & 0.21 & 0.15 & 0.18 & -0.02 & 0.69\end{array}$

$\begin{array}{llllllll}0.24 & 0.16 & 0.17 & 0.15 & 0.07 & 0.13 & 0.16 & 0.69\end{array}$

$\begin{array}{llllllll}0.17 & 0.09 & 0.29 & 0.15 & 0.06 & 0.16 & 0.05 & 0.69\end{array}$

$\begin{array}{llllllll}0.27 & 0.08 & 0.29 & 0.12 & 0.06 & 0.14 & 0.16 & 0.59\end{array}$

$\begin{array}{llllllll}0.08 & 0.08 & 0.11 & 0.23 & 0.19 & 0.06 & 0.07 & \mathbf{0 . 5 7}\end{array}$

Table 2. Descriptive Statistics and Correlations.

\begin{tabular}{|c|c|c|c|c|c|c|c|c|c|c|c|c|c|c|c|c|c|c|c|}
\hline & \multicolumn{2}{|c|}{ Mean } & \multicolumn{2}{|c|}{ SD } & \multicolumn{15}{|c|}{201312007} \\
\hline & 2007 & 2013 & 2007 & 2013 & & 1 & 2 & 3 & 4 & 5 & 6 & 7 & 8 & 9 & 10 & 11 & 12 & 13 & 14 \\
\hline 1 Gender & 0.583 & 0.568 & 0.494 & 0.496 & & $0.144^{* *}$ & 0.029 & $0.098^{*}$ & -0.057 & $-0.201 * *$ & $* 0.120 *$ & 0.066 & 0.035 & 0.002 & 0.073 & 0.040 & 0.053 & -0.018 & -0.035 \\
\hline 2 Age & 27.825 & 30.729 & 4.459 & 5.612 & 0.073 & & $0.805^{* *}$ & $0.365^{* *}$ & $0.590 * *$ & -0.024 & $0.569^{* *}$ & $0.096 *$ & 0.044 & 0.076 & -0.092 & $0.308^{* *}$ & $* 0.072$ & $0.124^{*}$ & $0.177 *$ \\
\hline 3 Tenure & 2.895 & 5.625 & 3.428 & 5.062 & -0.031 & $0.823^{*} *$ & & $0.188 * *$ & $0.557^{* *}$ & 0.068 & $0.548 * *$ & $0.106^{*}$ & 0.051 & 0.053 & -0.094 & $0.412 * *$ & $* 0.057$ & $0.157^{* *}$ & $0.190 * *$ \\
\hline 4 Turnover experience & 0.527 & 0.455 & 0.500 & 0.498 & -0.005 & 0.317 * & $0.150^{* *}$ & & $0.233^{*} *$ & -0.094 & $0.151^{* *}$ & 0.087 & 0.067 & $0.106^{*}$ & -0.027 & $0.117^{*}$ & 0.039 & $0.123^{*}$ & 0.063 \\
\hline 5 Marital status & 0.375 & 0.623 & 0.485 & 0.485 & 0.038 & 0.566 * & $0.518^{* *}$ & 0.250 ** & & 0.073 & $0.336^{* *}$ & 0.092 & 0.094 & $0.098 *$ & $-0.103^{*}$ & $0.276^{* *}$ & $* 0.075$ & $0.174^{* *}$ & $0.185 *$ \\
\hline 6 Indirect department & 0.683 & 0.698 & 0.466 & 0.460 & $-0.124 * *$ & -0.045 & -0.044 & -0.022 & -0.075 & & 0.009 & -0.050 & 0.077 & $-0.106^{*}$ & -0.043 & 0.049 & -0.067 & 0.035 & 0.059 \\
\hline 7 Position & 0.077 & 0.118 & 0.267 & 0.323 & 0.059 & $0.644 *$ & 0.579 ** & $0.109 * *$ & $0.240 * *$ & 0.042 & & 0.067 & 0.073 & $0.096^{*}$ & -0.088 & $0.210^{* *}$ & $* 0.130$ ** & 0.075 & $0.115^{*}$ \\
\hline 8 Supervisor support & 3.897 & 4.110 & 0.891 & 0.839 & -0.033 & 0.034 & $0.084 *$ & -0.052 & 0.045 & -0.013 & $0.157^{* *}$ & & $0.344^{* *}$ & $0.505 *$ & * -0.290 ** & $* 0.189 *$ & $* 0.420 * *$ & $* 0.324 * *$ & $0.390 * *$ \\
\hline 9 Co-worker support & 3.970 & 4.109 & 0.628 & 0.592 & -0.016 & -0.031 & 0.040 & -0.075 & 0.012 & 0.035 & $0.107 * *$ & 0.529 ** & & $0.470^{* *}$ & * $-0.263^{* * *}$ & * $0.243 *$ & * 0.334 ** & $* 0.132 * *$ & $0.352 * *$ \\
\hline 10 Benefit satisfaction & 2.865 & 3.329 & 0.921 & 0.938 & -0.064 & -0.008 & 0.015 & -0.049 & -0.047 & -0.029 & $0.136^{* *}$ & $0.440^{* *}$ & $0.351^{* *}$ & & -0.228 * & $* 0.085$ & $0.461^{* *}$ & $* 0.223^{* *}$ & $0.457 * *$ \\
\hline 11 Fatigue & 3.402 & 3.150 & 1.157 & 1.139 & $0.126 * *$ & $-0.116^{* *}$ & $-0.105 *$ & -0.026 & -0.061 & -0.015 & -0.156 * & * -0.142 ** & * -0.208 * & * -0.319 * & & -0.070 & $-0.238 *$ & $-0.12 \% *$ & $-0.236 * *$ \\
\hline 12 Autonomy & 3.901 & 3.898 & 0.805 & 0.686 & 0.041 & $0.345^{* *}$ & 0.350 ** & 0.061 & $0.275^{* *}$ & $-0.090 \%$ & $0.269^{* *}$ & $0.265^{*}$ & $0.267 *$ & $0.115^{* *}$ & $*-0.122$ ** & & $0.146 * *$ & $* 0.191 * *$ & $0.284 * *$ \\
\hline 13 Training provision & 3.396 & 3.935 & 0.982 & 0.858 & 0.003 & $-0.095^{*}$ & -0.024 & $-0.115^{* *}$ & -0.130 ** & $*-0.028$ & $0.084^{*}$ & $0.532^{* *}$ & $0.522 *$ & $0.513^{* *}$ & * -0.228 ** & $* 0.188 *$ & & $0.202 * *$ & $0.445^{* *}$ \\
\hline 14 Role clarity & 3.744 & 4.030 & 1.157 & 0.933 & -0.019 & -0.007 & 0.050 & -0.039 & 0.025 & -0.031 & 0.078 & $0.385^{* * *}$ & 0.379 ** & $0.293 *$ & * -0.231 * * & $* 0.236 * *$ & $* 0.362 * *$ & & 0.273 * \\
\hline 15 Organizational commitment & 3.828 & 3.942 & 0.804 & 0.744 & $-0.182 * *$ & $0.118 *$ & $0.162 * *$ & 0.019 & 0.058 & 0.005 & $0.176^{* * *}$ & $0.593^{* *}$ & $0.500 * *$ & $0.595 *$ & * -0.345 ** & $0.334 *$ & $* 0.555 *$ & $* 0.382 * *$ & \\
\hline
\end{tabular}


Table 3. Results of Hierarchical Regresson Analyses.

\begin{tabular}{|c|c|c|c|c|c|c|c|c|c|c|c|c|c|c|c|c|}
\hline \multirow[b]{2}{*}{ Variables } & \multicolumn{5}{|c|}{$\begin{array}{l}\text { Organizational commitment } \\
\text { (2007 and } 2013, n=1,005 \text { ) }\end{array}$} & \multicolumn{4}{|c|}{$\begin{array}{l}\text { Organizational commitment } \\
(2007, \mathrm{n}=429)\end{array}$} & \multicolumn{7}{|c|}{$\begin{array}{l}\text { Organizational commitment } \\
\qquad(2013, n=576)\end{array}$} \\
\hline & Step 1 & Step 2 & & Step 3 & & Step 1 & Step 2 & Step 3 & Step 4 & Step 1 & Step 2 & & Step & & Step & \\
\hline Gender & $-0.11^{* *}$ & $-0.10 *$ & $* *$ & -0.09 ** & ** & -0.02 & -0.05 & -0.04 & -0.05 & $-0.16^{* *}$ & $-0.15 *$ & ** & -0.13 & $* *$ & -0.13 & ** \\
\hline Age & 0.00 & 0.07 & & $0.10 *$ & * & 0.05 & 0.07 & 0.11 & 0.11 & -0.07 & 0.05 & & 0.07 & & 0.08 & \\
\hline Tenure & 0.08 & -0.01 & & 0.01 & & 0.08 & 0.04 & 0.01 & 0.00 & 0.08 & 0.03 & & 0.01 & & 0.01 & \\
\hline Turnover experience & 0.01 & 0.03 & & 0.02 & & 0.01 & -0.02 & -0.04 & -0.05 & 0.02 & 0.04 & & 0.07 & & $0.06 *$ & $*$ \\
\hline Marital status & 0.05 & -0.02 & & 0.00 & & 0.09 & 0.07 & 0.01 & 0.02 & 0.02 & -0.03 & & 0.00 & & -0.01 & \\
\hline Indirect department & -0.02 & 0.02 & & 0.02 & & 0.02 & 0.06 & 0.06 & 0.07 & -0.05 & -0.03 & & -0.01 & & -0.01 & \\
\hline Position & 0.06 & -0.03 & & $-0.07 *$ & * & -0.04 & -0.03 & -0.08 & -0.07 & $0.15^{* *}$ & 0.02 & & -0.05 & & -0.06 & \\
\hline Company 1 (dummy) & $-0.16 * *$ & $-0.10 *$ & $* *$ & -0.09 ** & ** & $-0.17 *$ & -0.09 & -0.06 & -0.05 & $-0.16^{* *}$ & $-0.11 *$ & $*$ & -0.12 & $* *$ & $-0.11 *$ & ** \\
\hline Company 2 (dummy) & $-0.10 * *$ & $-0.06 *$ & & -0.04 & & -0.03 & 0.02 & 0.01 & 0.02 & $-0.14 * *$ & $-0.12 *$ & $* *$ & -0.07 & $*$ & $-0.07 *$ & $*$ \\
\hline Company 3 (dummy) & -0.06 & 0.00 & & -0.01 & & -0.13 & -0.10 & -0.05 & -0.05 & -0.01 & -0.01 & & 0.04 & & 0.04 & \\
\hline \multicolumn{17}{|l|}{ Social rewards } \\
\hline Supervisor support & & $0.16 *$ & $* *$ & $0.09 *$ & & & 0.38 ** & & $0.10 *$ & & $0.57 *$ & $* *$ & & & $0.21 *$ & ** \\
\hline Co-worker support & & $0.09 *$ & $* *$ & $0.10 * *$ & ** & & & $0.11 *$ & $0.09 *$ & & & & 0.11 & $* *$ & $0.07 *$ & * \\
\hline \multicolumn{17}{|l|}{ Extrinsic rewards } \\
\hline Benefit satisfaction & & $0.26 *$ & $* *$ & $0.25 * *$ & ** & & & $0.27 * *$ & $0.24 * *$ & & & & 0.34 & $* *$ & $0.30 *$ & ** \\
\hline Fatigue & & $-0.07 *$ & $* *$ & -0.05 & & & & -0.05 & -0.06 & & & & -0.09 & $* *$ & $-0.07 *$ & * \\
\hline \multicolumn{17}{|l|}{ Intrinsic rewards } \\
\hline Autonomy & & $0.16 *$ & $* *$ & $0.14 * *$ & ** & & & $0.15^{* *}$ & $0.15 * *$ & & & & 0.17 & $* *$ & $0.15 *$ & ** \\
\hline Training provision & & $0.18 *$ & $* *$ & $0.22 * *$ & $* *$ & & & $0.23 * *$ & $0.21 * *$ & & & & 0.23 & $* *$ & 0.18 * & ** \\
\hline Role clarity & & $0.07 *$ & $* *$ & $0.08 *$ & & & & $0.10 *$ & 0.08 & & & & 0.10 & $* *$ & $0.08 *$ & * \\
\hline Sample & & & & -0.30 & & & & & & & & & & & & \\
\hline SamplexSupervisor support & & & & $0.30 *$ & & & & & & & & & & & & \\
\hline SamplexCo-worker support & & & & -0.11 & & & & & & & & & & & & \\
\hline SamplexBenefit satisfaction & & & & 0.07 & & & & & & & & & & & & \\
\hline SamplexFatigue & & & & -0.04 & & & & & & & & & & & & \\
\hline SamplexAutonomy & & & & 0.02 & & & & & & & & & & & & \\
\hline SamplexTraining provision & & & & -0.04 & & & & & & & & & & & & \\
\hline SamplexRole Clarity & & & & 0.00 & & & & & & & & & & & & \\
\hline $\mathrm{R}^{2}$ & 0.07 & 0.48 & & 0.49 & & 0.06 & 0.20 & 0.37 & 0.38 & 0.10 & 0.41 & & 0.57 & & 0.60 & \\
\hline Adjusted $\mathrm{R}^{2}$ & 0.06 & 0.47 & & 0.48 & & 0.04 & 0.17 & 0.35 & 0.35 & 0.08 & 0.40 & & 0.56 & & 0.58 & \\
\hline $\mathrm{F}$ & $7.62 * *$ & $52.70 *$ & $* *$ & $37.72 * *$ & ** & $2.76 * *$ & $9.20 * *$ & $15.31 * *$ & $14.78 * *$ & $6.33 * *$ & $35.48 *$ & $* *$ & 46.78 & *** & $48.45^{*}$ & ** \\
\hline
\end{tabular}

In separate regression analysis using the 2007 and the 2013 data, we entered the control variables in Step 1, and main effects of supervisor support, co-worker support, benefit satisfaction, fatigue, autonomy, training provision and role clarity in Step 4. In Step 2 to 3, main effects were separately entered by supervisor support in Step 2 and other rewardsin Step 3 to test their comparative importance. All the five reward variables, except fatigue of the 2007, were significantly associated with OC when they were entered separately in Step 2 to 3 ( $p<0.05$ ). Observing adjusted R2, supervisor support and other rewards explained $13 \%$ and $31 \%$ of additional variances in OC respectively in the 2007 data. On the other hand, these figures were $32 \%$ and $48 \%$ in the 2013 data. These imply that both supervisor support and other rewardswere important for OC in both years butthe formeris more important comparatively and absolutely in 2013 than in 2007, confirming Hypotheses 1.

\section{Discussion and Implications for Theory and Practice}

The objective of the present study was to investigate the change between 2007 and 2013 in antecedents of the organizational commitment (OC) of university-graduate employees working in the Japanese companies in China. Our findings demonstrate that seven rewards (i.e. supervisor support, co-worker support, benefit satisfaction, autonomy, training provision, role clarity and lower fatigue) engendered higher levels of OC. This is in line with the previous research (e.g. Nazir, 2016) and indicates there are many rewards to enhance OC of Chinese university graduates. However, we found a difference in the significance of correlation between supervisor support and OC between the samples of 2007 and 2013. The result indicates that university graduates in Japanese companies had become to require more support from supervisors in 2013 than they did in 2007.

This finding was consistent with the hypothesis and in line with the indication of previous research regarding Chinese society asit has been argued that Chinese culture is largely collectivistic (Triandis, 1995) and employees' OC in such asociety may arise from ties with supervisors and surrounding people (Boyacigiller \& Adler, 1991). However, empirical evidence suggests that individualism in China could be increasing in the long run (Yan, 2009) because culture in a society tends to shift to individualism as it develops economically (Triandis, 1995; Hofstede, 2001). Supposing such a correlation between economic condition and individualism, we can reasonably expect that a society may advance backward intensifying its collectivistic feature when it is under economic slowdown. Accordingly, it is considered that the economic crisis in 2008 and the following long-lasting hard times hadmade 
the university graduates feel more anxious, become more collectivistic and seek for more support from the bosses than they did before. Such a retrograde movement may possibly have been intensified by Chinese past-oriented culture where they tend to be high in uncertainty avoidance and moreuncomfortable with change than Western people (Rarick, 2007).

However, the result that co-worker support, which is another fragment of social rewards, showed no significant change in relation with OC contradicts our hypothesis. What is the reason of such difference? To obtain a hint for answering this question, we may have to remember another cultural feature of this country in which there is respect for seniority, strict hierarchies in the workplace and limited subordinate participation in decision-making (Chan, et al., 2006; Cheng, et al., 2003; Chen, et al., 2002). As people had much accounted of seniority in their human relations due mainly to traditional Confusion culture, they may have come to more rely on such relations when they became anxious under economic slowdown because relations with the bosses are not merely related with collectivism but also with the Confucian ethical view which has taken root in general in this society. On the other hand, relations with co-workers are considered to be less related with such tradition and may not change its importance as a factor of OC even in the hard time.

This result is full of interesting suggestion for considering the future of management in China. Although recent empirical studies highlight the growing importance of participative leadership in various enterprises in exchange of abandoning traditional authoritarian and command-based styles (Huang, Iun, Liu, \& Gong, 2010), there has been limited focus on its relevance in the period of slowdown. Based on the finding in this research andtaking account the Chinese past-oriented features, more flexible HRM which allowssome adjustments depending on economic conditions might be more acceptable for Chinese graduate employees than those which require selecting one style from two alternatives irrespective the situations which confront them. However, at the same time, we may not have to exaggerate the necessity of going back to the past because this research indicates that employees' response to the most rewards including intrinsic and extrinsic rewards which are said to be stronger in individualistic culture (Boyacigiller \& Adler, 1991) do not change over time. This result may be understood that individualism is not weakened even during the economic slowdown because individualism is not the polar opposite of collectivism (Triandis, et al., 1988) and Chinese society has adopted market economic principles and become more individualistic without substantially forsaking their collectivistic Confucian culture (Ralston, Nguyen, \& Napier, 1999). In other words, they may need to be more collectivistic to soften anxiety in the depression but may not need to be less individualistic as individualism may coexist with collectivism. Accordingly, building good teamwork with supervisors and co-workers, removing irrational quantities from treatments, enriching opportunities of self-enhancement, clarifying job scope and enhancing a sense of autonomy by delegation of organizational authority (an area in which Japanese companies are weak. Cf. Yu \& Meyer-Ohle, 2008) are all important and should be considered comprehensively anytime irrespective of economic conditions.

Additionally, we could examine local adaptability of the management of Japanese companies in a time of recession. Japanese companies is sometimes considered to be a second family which encourages intensive socialization (Jackson \& Tomioka, 2004) and require managers closely involved with a work group (Whitney, 1994, p.100), even though nowadays Japanese management changes and parts from such family-like style due to economic stagnation and the influence of globalization (Haghirian, 2010). In this sense, Japanese companies may possibly adapt themselves to Chinese work conditions especially when the latter is under a circumstance of economic stagnation and becomes more collectivistic than usual. However, we may not take an optimistic view remembering the fact that Japanese managers are typically less trusted from their subordinates than Chinese counterparts especially for job performing ability, leadership and capability for managing subordinates (Shiraki, 2012). Accordingly, collectivistic culture of Japanese companies may not be attractive for the employees even in the hard time, rather, could become harmful to soundness of the management through the channel of strengthened effect of supervisor support towards OC in the economic slowdown. Off course, the supervisors in Japanese companies are not only Japanese but also Chinese, but the latter may also be inferior to those of other kind of companies in their skills of managing subordinates as Japanese companies are known not to be selected by uni versity graduates as the workplaces they primarily want to work for (Zhang, 2003) and as the result not a few Chinese managers there may be the ones who couldn't enter other kind of companies. Accordingly, Japanese companies may need to improve the HRM in China to attract better managers and to enhance the employees' OC even in a depression by strengthening the support from supervisors to subordinates through enriched education to the former, localization of the management by transferring authority from Japanese expatriates to local staffs, etc.

\section{Study Limitations and Suggestions for Future Research}

There are three significant limitations on this research. The first one is about target. The sample in this research 
targeted only four Japanese manufacturing companies. If the sample includes larger number of companies of diverse industries of various origins, the results may perhaps be altered.

The second limitation is applicability. The incident which occurred and influenced the nature of employees between 2007 and 2013 may not only the economic slowdown but also a product of many other occurrences unmentioned in this paper. So, to further consider the change of rewards-OC relationship over time, future research is recommended to take account more various possibilities.

The third limitation of this research is about reliability. This study used self-report data from single respondents, which may have resulted in common method bias. Future research might consider the inclusion of supervisor-rated scales to reduce common method bias and remedy the weakness of the present study design.

\section{References}

Aiken, L. S., \& West, S. G. (1991). Multiple regression: Testing and interpreting interactions. Thousand Oaks, CA: Sage.

Allen, N. J., \& Meyer, J. P. (1990). The measurement and antecedents of affective, continuous, and normative commitment to the organization. Journal of Occupational Psychology, 63(1), 1-18. https://doi.org/10.1111/j.2044-8325.1990.tb00506.x

Barrett, A., \& O'Connell, P. J. (2001). Does training generally work? The returns to in-company training. Industrial and Labor Relations Review, 54(3), 647-662. https://doi.org/10.1177/001979390105400307

Beukhof, G., De Jong, M. J., \& Nijhof, W. J. (1998). Employee commitment in changing organization: An exploration. Journal of European Industrial Training, 22(6), 243-248. https://doi.org/10.1108/03090599810224701

Boyacigiller, N., \& Adler, N. J. (1991). The parochial dinosaur: Organizational suicide in global context. Academy of Management Review, 16, 262-290. https://doi.org/10.5465/AMR.1991.4278936

Caught, K., \& Shadur. (2000). The measurement artifact in the organizational commitment questionnaire. Psychological Reports, 87(3), 777-788. https://doi.org/10.2466/pr0.2000.87.3.777

Chan, A. W., Feng, T. Q., Redman, T., \& Snape, E. (2006). Evaluating the multi-dimensional view of employee commitment: A comparative UK-Chinese study. International Journal of Human Resource Management, 17(11), 1873-1887. https://doi.org/10.1080/09585190601000022

Chen, Z. X., \& Aryee, S. (2007). Delegation and employee work outcomes: An examination of the cultural context of mediating processes in China. Academy of Management Journal, 50, 226-238. https://doi.org/10.5465/AMJ.2007.24162389

Chen, Z. X., Tsui, A. S., \& Farth, J. L. (2002). Loyalty to supervisor vs. organizational commitment: Relationships to employee performance in China. Journal of Occupational and Organizational Psychology, 75(3), 339-356. https://doi.org/10.1348/096317902320369749

Cheng, B. S., Jiang, D. Y., \& Riley, J. H. (2003). Organizational commitment, supervisory commitment, and employee outcomes in the Chinese context: Proximal hypothesis or global hypothesis? Journal of Organizational Behavior, 24(3), 313-334. https://doi.org/10.1002/job.190

Chiu, R. K., Luk, V. W. M., \& Tang, T. L. P. (2002). Retaining and motivating employees: Comparison preferences in Hong Kong and China. Personnel Review, 31, 402-431. https://doi.org/10.1108/00483480210430346

Colignon, R. A., Usui, C., Kerbo, H., \& Slagter, R. (2007). Employee commitment in US and Japanese firms in Thailand. Asian Social Science, 3(11), 16-32. Retrieved from http://digitalcommons.calpoly.edu/cgi/viewcontent.cgi?article=1051\&context=ssci_fac

Eby, L. T., Freeman, D. M., Rush, M. C., \& Lance, C. E. (1999). Motivational bases of affective organizational commitment: A partial test of an integrative theoretical model. Journal of Occupational and Organizational Psychology, 72(4), 463-483. https://doi.org/10.1348/096317999166798

Froese, F. J., \& Xiao, S. (2012). Work values, job satisfaction and organizational commitment in China. The International Journal of Human Resource Management, 23(10), 2144-2162. https://doi.org/10.1080/09585192.2011.610342

Gamble, J., \& Tian, A. W. (2015). Intra-national variation in organizational commitment: evidence from the Chinese context. The International Journal of Human Resource Management, 26(7), 948-970. 
https://doi.org/10.1080/09585192.2012.722122

Gregersen, H. B., \& Black, J. S. (1996). Multiple commitments upon repatriation: The Japanese experience. Journal of Management, 22(2), 209-229. https://doi.org/10.1177/014920639602200202

Haghirian, P. (2010). Innovation and Change in Japanese Management, Springer. https://doi.org/10.1057/9780230250536

He, Y., Lai, K. K., \& Lu, Y. (2011). Linking organizational support to employee commitment: Evidence from hotel industry of China. International Journal of Human Resource Management, 22(1), 197-217. https://doi.org/10.1080/09585192.2011.538983

Hofstede, G. (2001). Culture 's consequences (2nd ed). Beverly Hills, CA: Sage Publications.

Hofstede, G. (1980). Culture's consequence. Beverly Hills, CA: Sage Publications.

Hou, Y., Gao, G., Wang, F., Li, T., \& Yu, Z. (2011). Organizational commitment and creativity: the influence of thinking styles. Annals of Economics \& Finance, 12(2), 411-431. Retrieved from http://aefweb.net/aefarticles/aef120209.pdf

Huang, X., Iun, J., Liu, A., \& Gong, Y. (2010). Does participative leadership enhance work performance by inducing empowerment or trust? The differential effects on managerial and non-managerial subordinates. Journal of Organizational Behavior, 31(1), 122-143. https://doi.org/10.1002/job.636

International Monetary Fund (2017). World Economic Outlook Databases April 2017. Retrieved from http://www.imf.org/external/ns/cs.aspx?id=28

Jackson, K., \& Tomioka, M. (2004). The Changing Face of Japanese Management, London: Routledge.

Jafri, M. H. (2010). Organizational commitment and employee's innovative behavior: A study in retail sector. Journal of Management Research, 10(1), 62-68.

Jamal, M. (2005). Personal and organizational outcomes related to job stress and Type-A behavior: a study of Canadian and Chinese employees, Stress and Health, 21(2), 129-137. https://doi.org/10.1002/smi.1047

Japan External Trade Organization. (2016). 2015 nen no taichu chokusetsu toshi doko (Direct investment trend in China 2015), July 2016. (Japanese). https://www.jetro.go.jp/world/reports/2016/01/12f11b2258f74978.html

Japan-China Investment Promotion Organization. (2005). Dai 8 ji nikkei kigyo anketo chosa shukei kekka (gaiyo) (Aggregated results of the 8th survey of Japanese companies), October 2005. (Japanese)

Kokubun, K. (2006). Globalization and industrial reallocation: How to motivate Malaysian workers. Paper presented at the 3rd International Globalization Studies Network (GSN) Conference, Universiti Kebangsaan Malaysia.

Kokubun, K. (2017a). Organizational commitment and rewards in Thailand, with comparison between uni versity graduates and others. Asian Social Science, 13(6), 1-19. https://doi.org/10.5539/ass.v13n6p1

Kokubun, K. (2017b). The moderating effect of gender on the organizational commitment-rewards relationship. International Journal of Business and Management, 12(7), 1-16. https://doi.org/10.5539/ijbm.v12n7p1

Lam, C. S., \& O'Higgins, E. R. E. (2011). Enhancing employee outcomes: The interrelated influences of managers' emotional intelligence and leadership style. Leadership \& Organization Development Journal, 33(2), 149-174. https://doi.org/10.1108/01437731211203465

Malhotra, N., Budhwar, P., \& Prowse, P. (2007). Linking rewards to commitment: An empirical investigation of four UK call centres. International Journal of Human Resource Management, 18(12), 2095-2128. https://doi.org/10.1080/09585190701695267

Meyer, J. P., Stanley, D. J., Herscovitch, L., \& Topolnytsky, L. (2002). Affective, continuance, and normative commitment to the organization: A meta-analysis of antecedents, correlates, and consequences. Journal of Vocational Behavior, 61(1), 20-52. https://doi.org/10.1006/jvbe.2001.1842

Miao, Q., Newman, A., Sun, Y., \& Xu, L. (2013). What factors influence the organizational commitment of public sector employees in China? The role of extrinsic, intrinsic and social rewards. International Journal of Human Resource Management, 24(17), 3262-3280. https://doi.org/10.1080/09585192.2013.770783

Milfont, T. L., \& Fischer, R. (2010). Testing measurement invariance across groups: Applications in cross-cultural research. International Journal of Psychological Research, 3, 111-121. https://doi.org/10.21500/20112084.857 
Ming, L., \& Zhao ying, Z. (2010). How does organizational commitment affect organizational innovation. 2010 International Conference on E-Business and E-Government, 1164-1170. Institute of Electrical and Electronics Engineers. https://doi.org/10.1109/ICEE.2010.300

Ministry of Economy, Trade and Industry of Japan. (2016). Dai 46 kai kaigai jigyo katsudo kihon chosa gaiyo (Summary report: 46th basic survey of foreign business activities). (Japanese) Retrieved from http://www.meti.go.jp/statistics/tyo/kaigaizi/result/result_46/pdf/h2c46kaku1.pdf

Mottaz, C. J. (1985). The relative importance of intrinsic and extrinsic rewards as determinants of work satisfaction. The Sociological Quarterly, 26(3), 365-385. https://doi.org/10.1111/j.1533-8525.1985.tb00233.x

Mowday, R. T., Porter, L. W., \& Steers, R. M. (1982). Employee-organization linkages: The psychology of commitment, absenteeism and turnover. New York, NY: Academic Press.

Nazir, S., Shafi, A., Qun, W., Nazir, N., \& Tran, Q. D. (2016). Influence of organizational rewards on organizational commitment and turnover intentions. Employee Relations, 38(4), 596-619. https://doi.org/10.1108/ER-12-2014-0150

Newman, A., \& Sheikh, A. Z. (2012). Organizational commitment in Chinese small- and medium-sized enterprises: The role of extrinsic, intrinsic and social rewards. International Journal of Human Resource Management, 23(2), 349-367. https://doi.org/10.1080/09585192.2011.561229

Newman, A., Thanacoody, R., \& Hui, W. (2011). The impact of employee perceptions of training on organizational commitment and turnover intentions: A study of multinationals in the Chinese service sector. International Journal of Human Resource Management, 22(8), 1765-1787. https://doi.org/10.1080/09585192.2011.565667

O'Reilly, C. A., \& Caldwell, D. F. (1980). Job choice: The impact of intrinsic and extrinsic factors on subsequent satisfaction and commitment. Journal of Applied Psychology, 65(5), 559-565. https://doi.org/10.1037/0021-9010.65.5.559

Peyyer, C., Jordan, C., Firms, I., \& Travaglione, A. (2010). Predicting turnover intentions. Management Research Review, 33(9), 911-923. https://doi.org/10.1108/01409171011070323

Phipps, S. T., Prieto, L. C., \& Ndinguri, E. N. (2013). Understanding the impact of employee involvement on organizational productivity: The moderating role of organizational commitmen. Journal of Organizational Culture, Communication and Conflict, 17(2), 107.

Porter, L. W., \& Lawler, E. E. (1968). Managerial attitudes and performance. Homewood, IL: Dorsey Press.

Ralston, D. A, Nguyen, V. T., \& Napier, N. K. (1999). A comparative study of the work values of north and south Vietnamese managers. Journal of International Business Studies, 30(4), 655-672. https://doi.org/10.1057/palgrave.jibs.8490097

Ralston, D. A., Holt, D. H., Terpstra, R. H., \& Kai-Cheng, Y. (2008). The impact of national culture and economic ideology on managerial work values: A study of the United States, Russia, Japan, and China. Journal of International Business Studies, 39(1), 8-26. https://doi.org/10.1057/palgrave.jibs.8400330

Rarick, C. A. (2007). Confucius on management: Understanding Chinese cultural values and managerial practices. Journal of International Management Studies, 2(2), 22-28. Retrieved from http://www.jimsjournal.org/3\%20Charles.pdf

Recruit Management Solutions. (2012). Chugoku ni okeru Nikkei kigyo no image to daigakusei ga kigyo ni motomeru koto (Image towards Japanese companies in China and what university students ask companies for). (Japanese) Retrieved from https://www.recruit-ms.co.jp/research/study_report/0000000290/

Sharma, Y. (2014). What do you do with millions of extra graduates? BBC News. 1 July 2014. Retrieved from http://www.bbc.com/news/business-28062071

Shibata, H. (2015). Personnel management of Japanese companies in China (5): Personnel management problems of this stage. Sensyu Ningenkagaku Ronsyu Shakaigakuhen, 5(2), 51-67. (Japanese) Retrieved from file:///C:/Users/user/Downloads/1072_0005_09\%20(1).pdf

Shiraki, M. (2012). Nihon Kigyo no globalization to kaigai hakensha: Asia no genchi staff niyoru joshi hyoka karano kento (Japanese companies' globalization and overseas expatriates: Examination by local staffs' evaluation towards supervisors in Asia). Nihon Rodo Kenkyu Zasshi, 623, 5-16. (Japanese) Retrieved from http://www.jil.go.jp/institute/zassi/backnumber/2012/06/pdf/005-016.pdf 
Steers, R. M. (1977). Antecedents and outcomes of organizational commitment. Administrative Science Quarterly, 22(1), 46-56. https://doi.org/10.2307/2391745

The Japanese Chamber of Commerce and Industry in China (2016). Chugoku keizai to nihon kigyo 2016 nen hakusyo (Chinese economy and Japanese companies 2016 white paper). (Japanese). Retrieved from http://www.cjcci.biz/public_html/whitepaper/.../hakusho_full_JP.pdf

Triandis, H. C. (1995). Individualism and Collectivism. Boulder, CO: Westview Press.

Triandis, H. C., Bontempo, R., Villareal, M. J., Asai, M. \& Lucca, N. (1988). Individualism and collectivism: Cross-cultural perspectives on self-ingroup relationships. Journal of Personality and Social Psychology, 54(2), 323-338. https://doi.org/10.1037/0022-3514.54.2.323

United Nations Conference on Trade and Development. (2004). World investment report 2004: The shift towards services. New York and Geneva: United Nations. Retrieved from http://unctad.org/en/Docs/wir2004_en.pdf

United Nations Conference on Trade and Development. (2010). World investment report 2010. New York and Geneva: United Nations. Retrieved from http://unctad.org/en/Docs/wir2010_en.pdf

Wan, S. (2009). Chugoku shinsyutsu Nikkei kigyo no rodo CSR (Labor CSR of Japanese companies in China). (Japanese) Retrieved from http://www.ipp.hit-u.ac.jp/consultingproject/2009/CP09Wang.pdf

Warner, M. (2004). Human resource management in China revised: Introduction. International Journal of Human Resource Management, 15(4-5), 617-634. https://doi.org/10.1080/0958519042000192861

Wasti, S. A. (1998). Cultural barriers in the transferability of Japanese and American human resources practices to developing countries: the Turkish case. International Journal of Human Resource Management, 9(4), 608-631. https://doi.org/10.1080/095851998340928

Whitney, R. (1994). Business systems in Asia: Firms, markets and societies. London, Newbury Park, Sage publications.

Yan, X. (2010). Nihon kigyo niyoru taichu sinsyutu no chiiki bunpu (Japanese companies' regional distribution in China). Retrieved from http://www.osaka-ue.ac.jp/zemi/kusanagi/2009nagizemi/pdf/02_Yan.pdf

Yan, Y. X. (2009). The individualization of Chinese society. Oxford: Berg.

Yu, J., \& Meyer-Ohle, H. (2008). Working for Japanese corporations in China: A qualitative study. Asian Business and Management, 7(1), 33-51.https://doi.org/10.1057/palgrave.abm.9200250

Zhang, J. (2003). Nikkei kigyo no jinji romu kanri to chingin mondai: Kawaru Chugokujin no ishiki to kawaranu Nihongata keiei (The labor management of Japanese companies and the problems of its wage system: The changing concepts of Chinese and the changeless Japanese management). Asia Market Review, 15(10), 34-36. (Japanese) Retrieved from http://chasechina.jp/reports/chinabiz/resources/401.html

Zhou, M., \& Lin, J. (2009). CHINA: Graduate unemployment on the rise. University World News, 71. universityworldnews.com. 12 April 2009. Retrieved from http://www.universityworldnews.com/article.php?story=20090409203634912 
Appendix. Demographic Information.

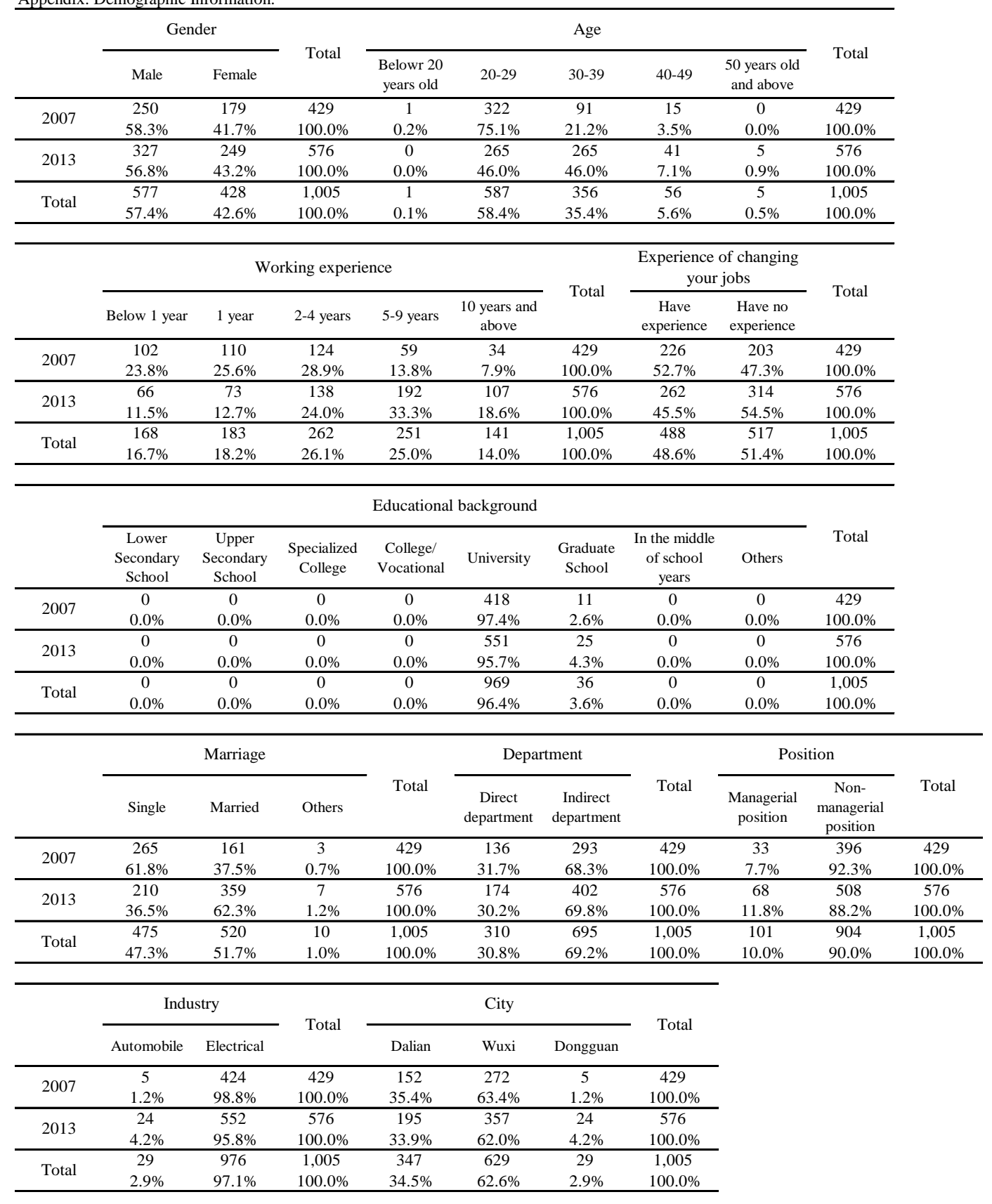

\section{Copyrights}

Copyright for this article is retained by the author(s), with first publication rights granted to the journal.

This is an open-access article distributed under the terms and conditions of the Creative Commons Attribution license (http://creativecommons.org/licenses/by/4.0/). 